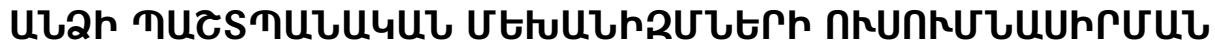

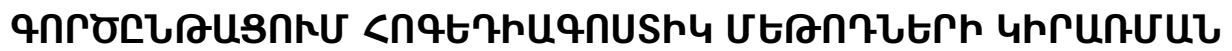

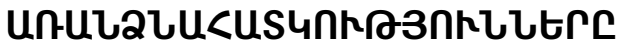

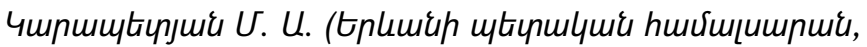

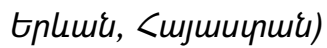

karapetyanmargarita111@gmail.com

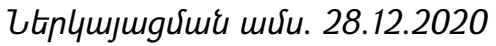

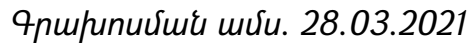

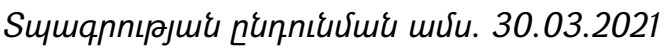

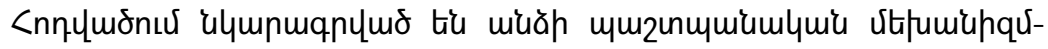

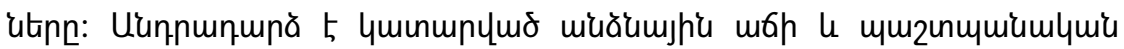

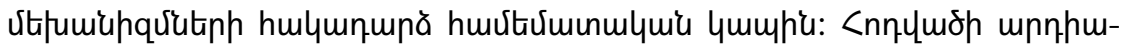

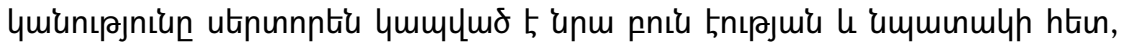

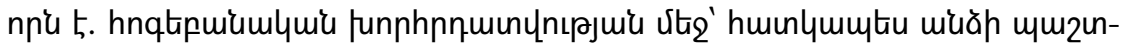

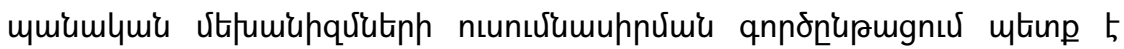

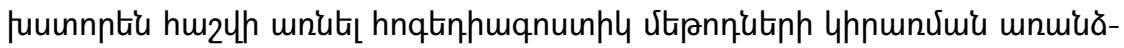

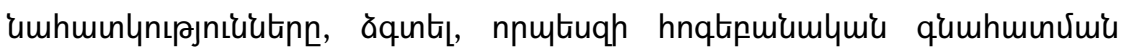

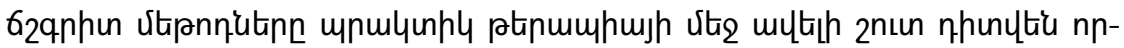

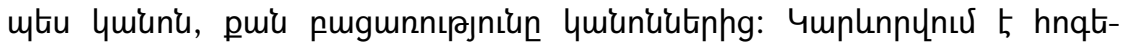

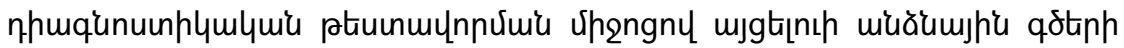

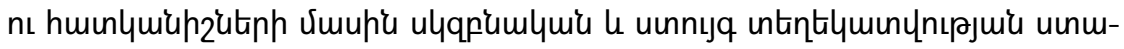

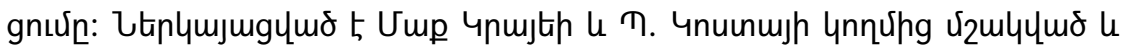

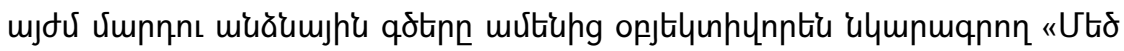

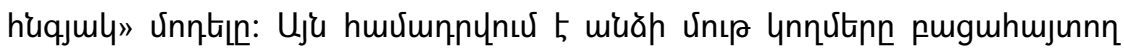

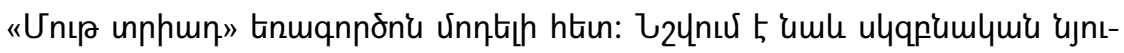

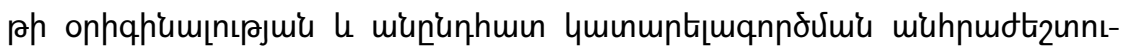

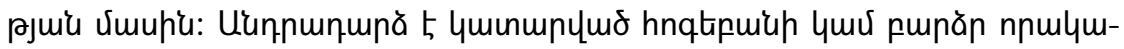

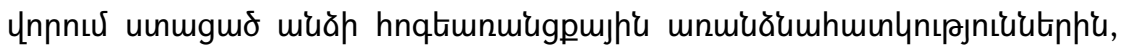

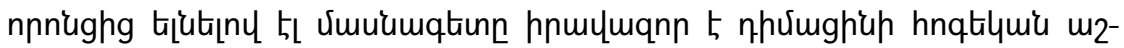

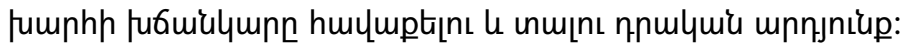

DOI: https://doi.org/10.46991/SBMP/2021.4.1.069

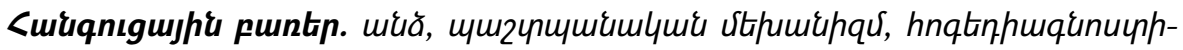
чm, ptiuytin, hungunwiu, unnjtilghw:

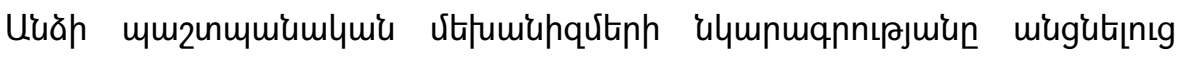

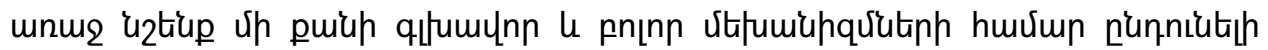

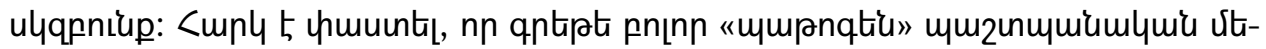




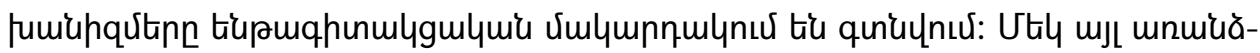

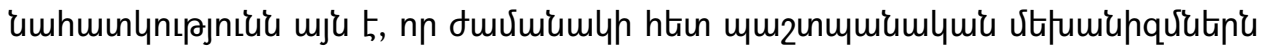

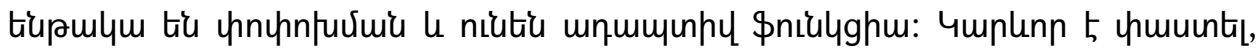

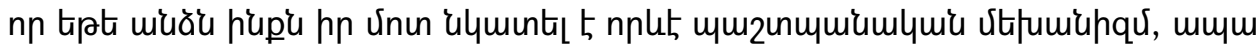

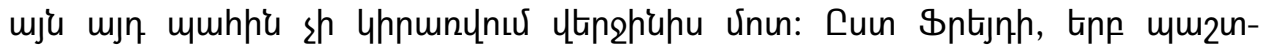

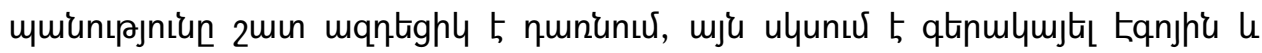

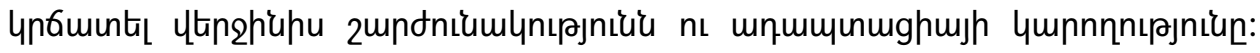

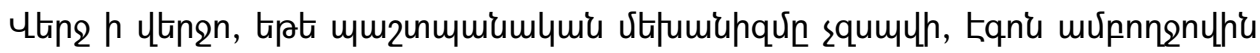

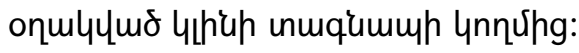

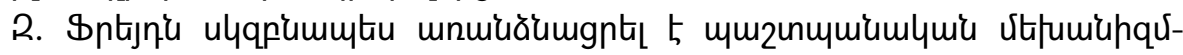

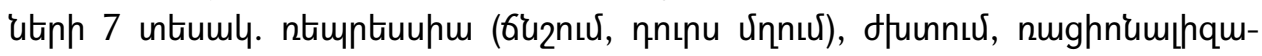

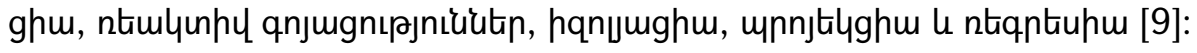

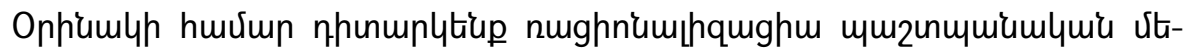

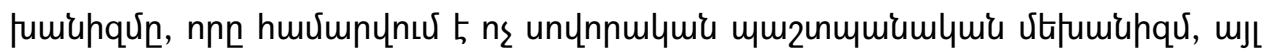

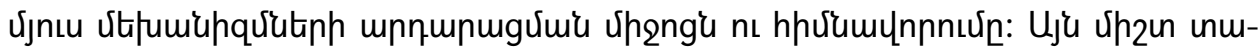

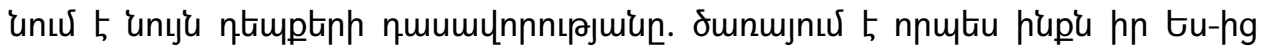

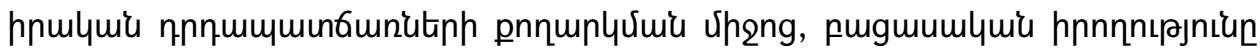

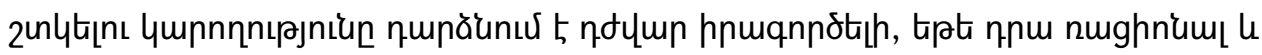

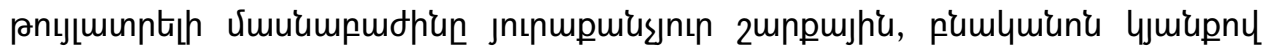

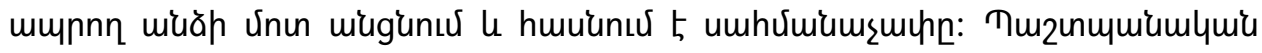

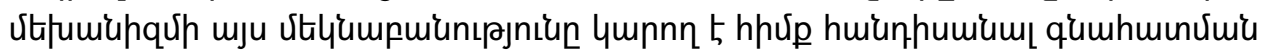

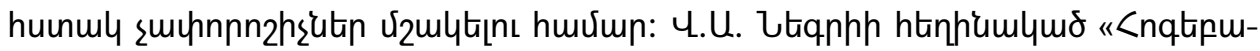

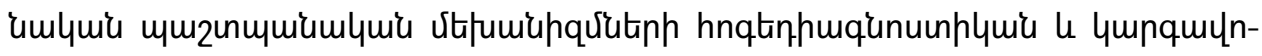

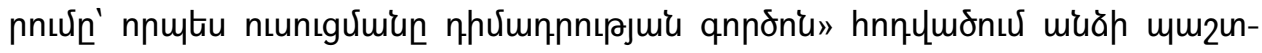

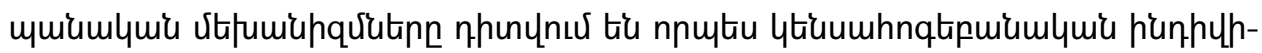

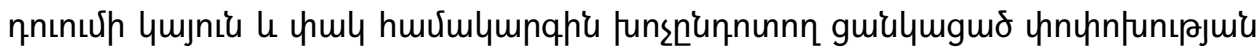

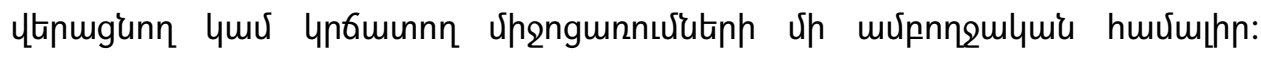

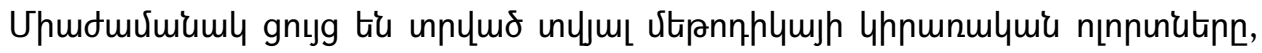

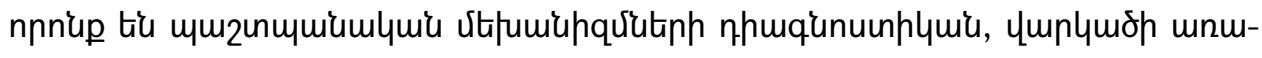

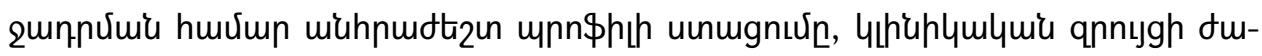

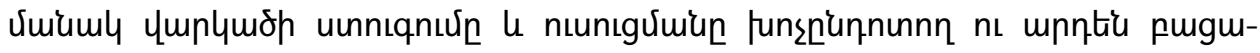

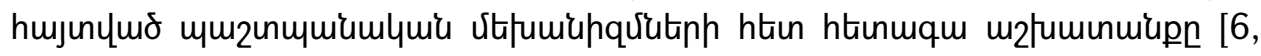
52 175-180]:

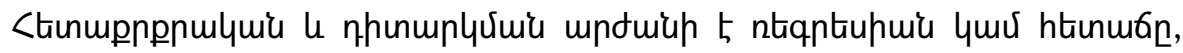

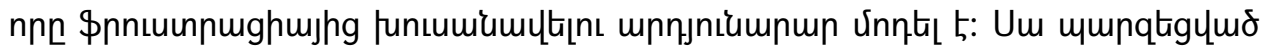

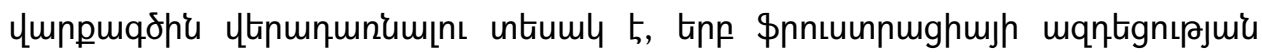

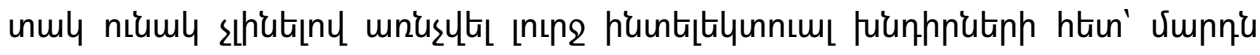

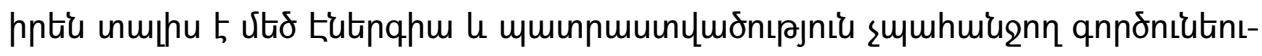

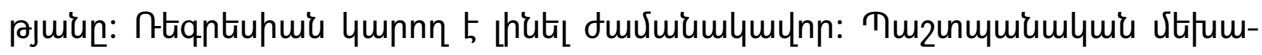

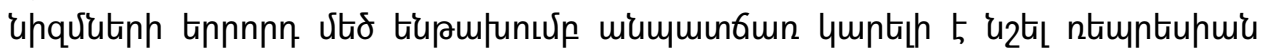




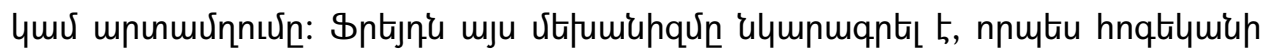

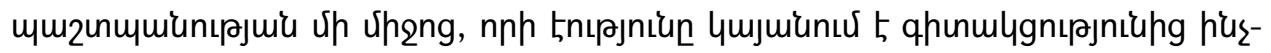

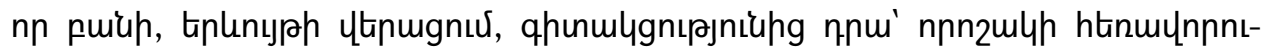

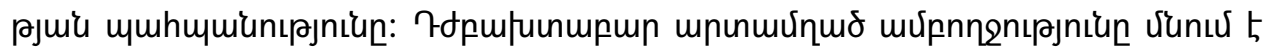

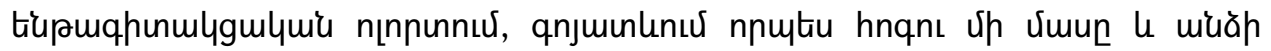

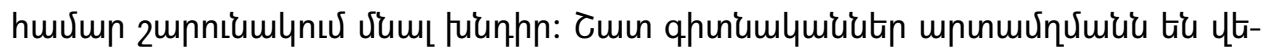

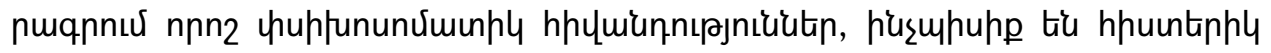

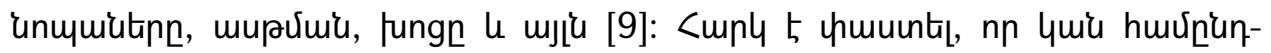

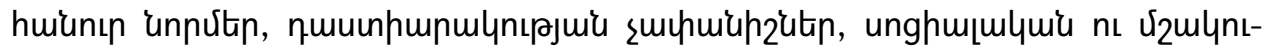

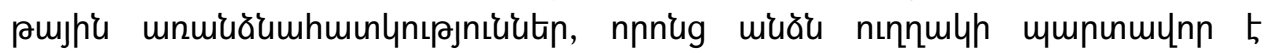

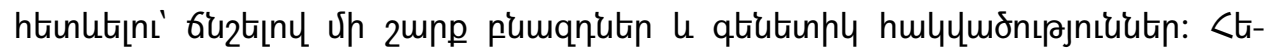

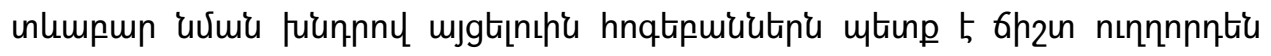

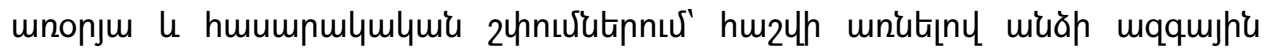

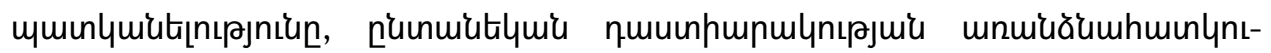

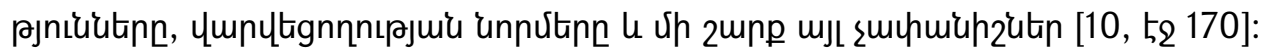

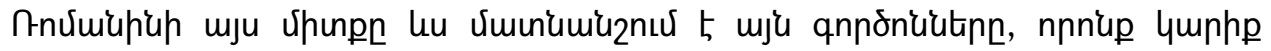

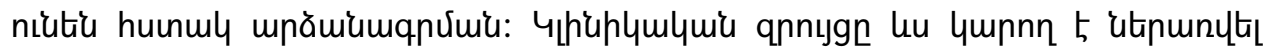

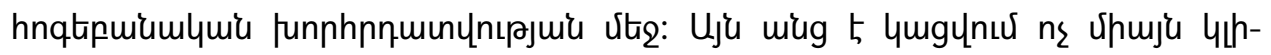

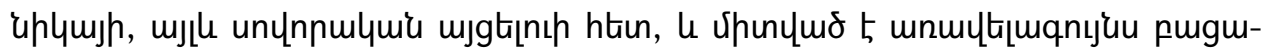

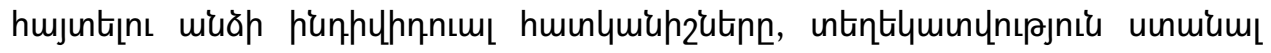

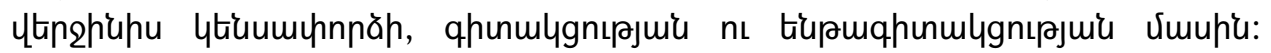

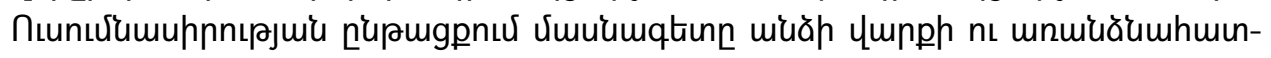

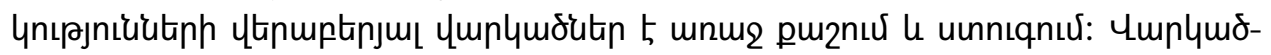

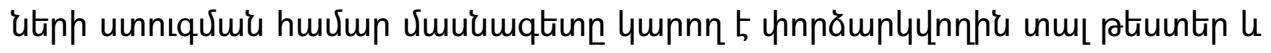

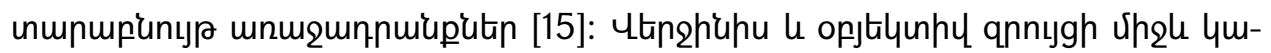

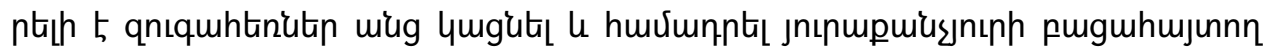

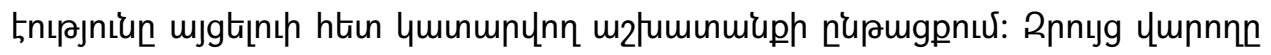

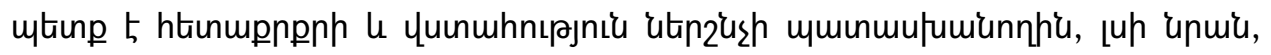

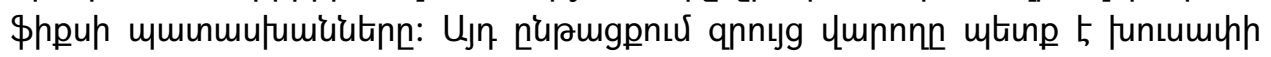

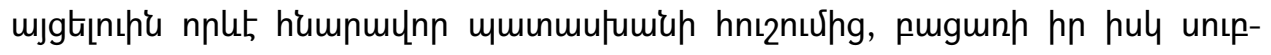

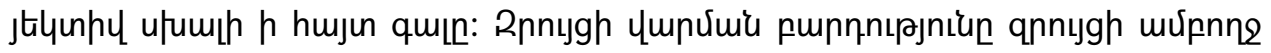

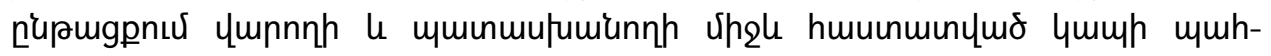

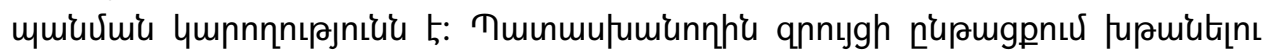

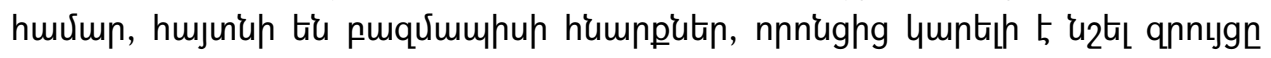

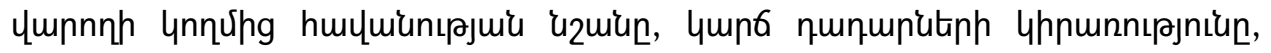

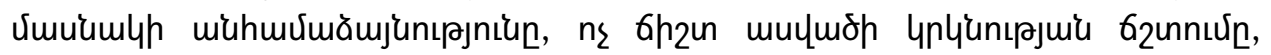

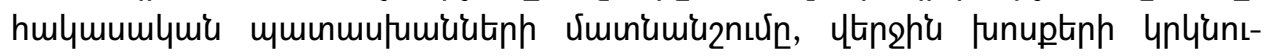
pjniun u m.lu [16]:

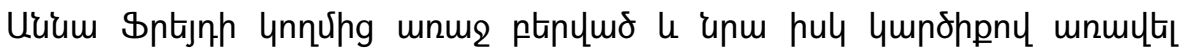

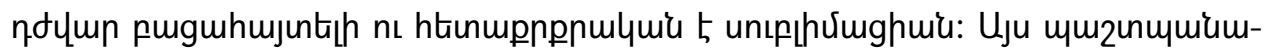




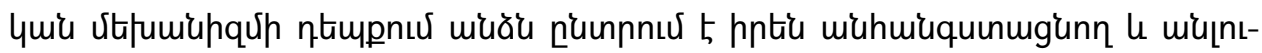

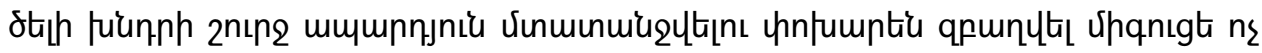

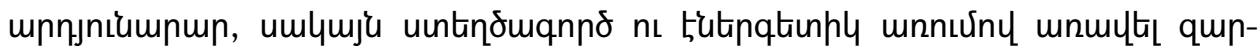

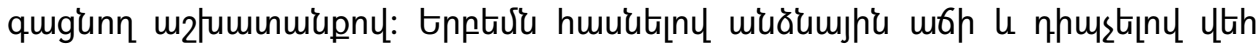

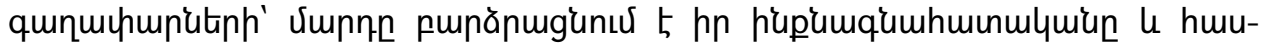

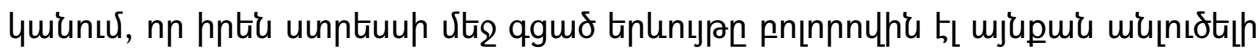

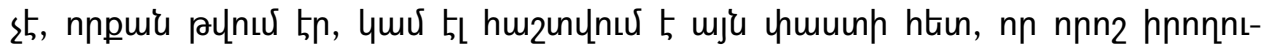

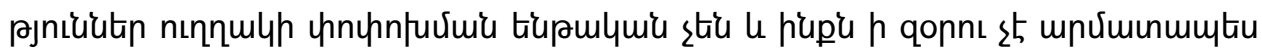

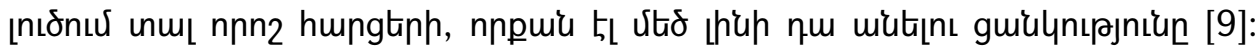

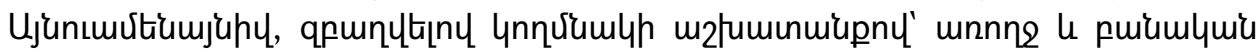

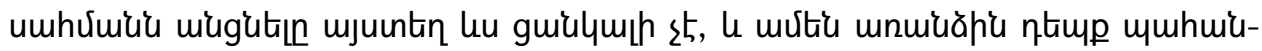
2nuर 5 hnqtiptinumulunply untinh'u ununtignus:

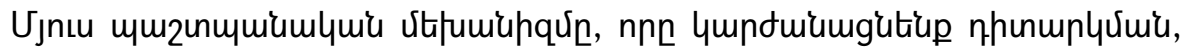

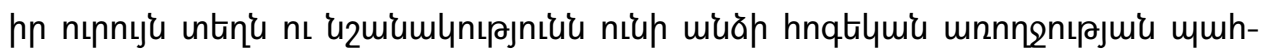

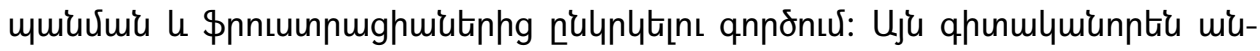

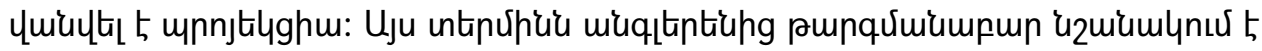

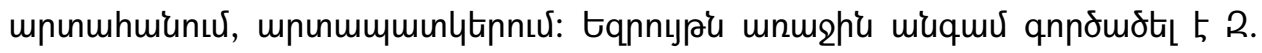

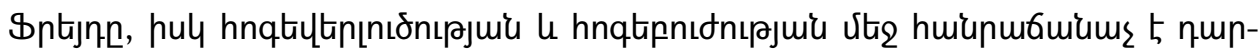

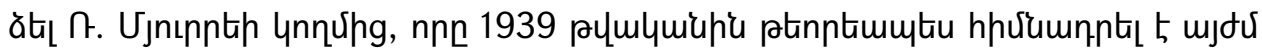

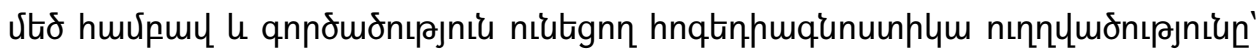

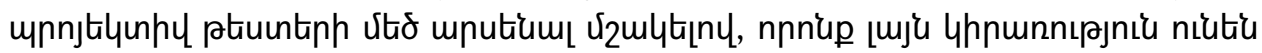

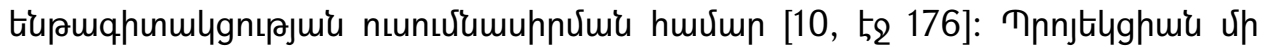

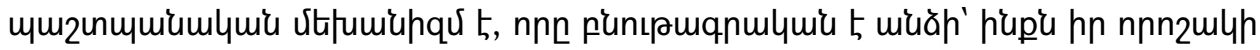

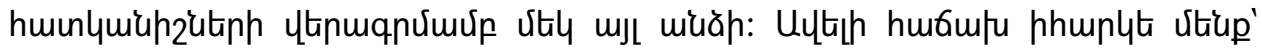

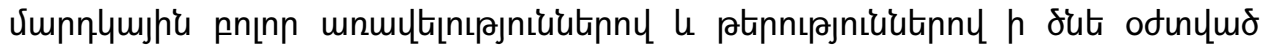

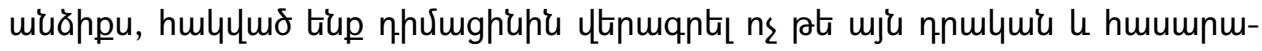

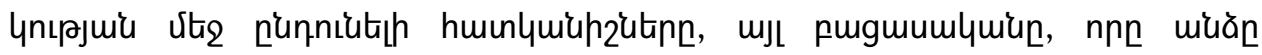

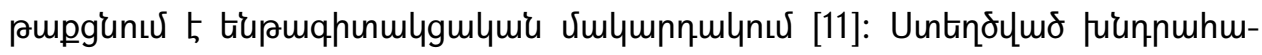

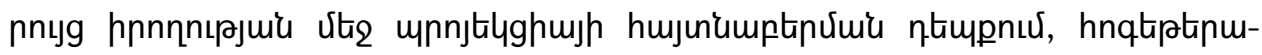

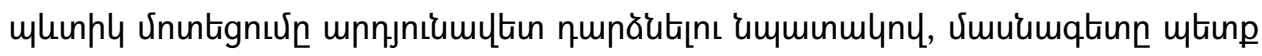

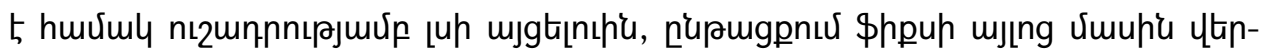

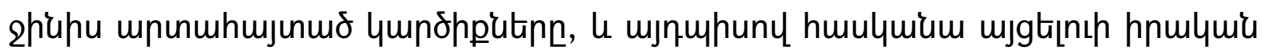

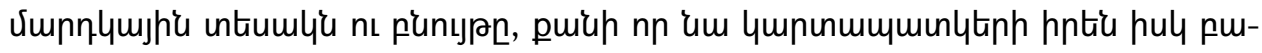

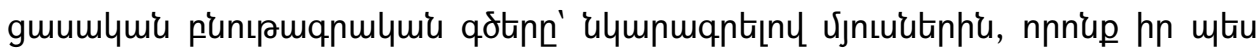

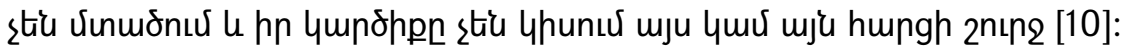

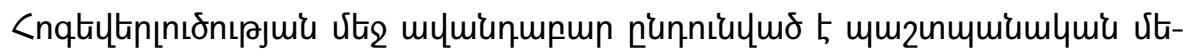

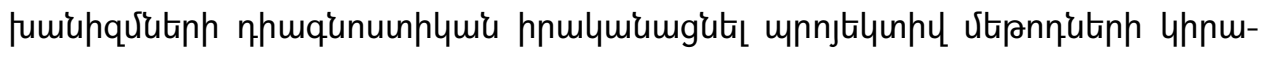

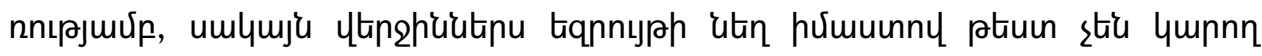

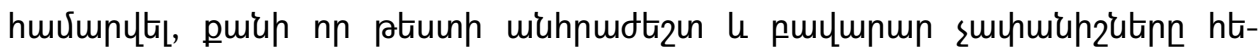

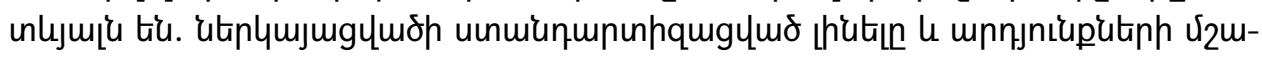




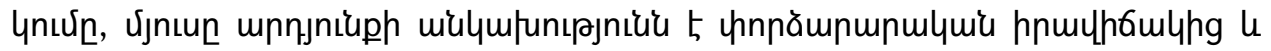

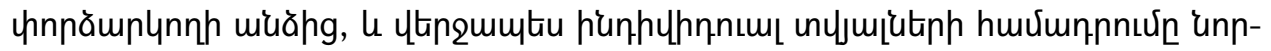

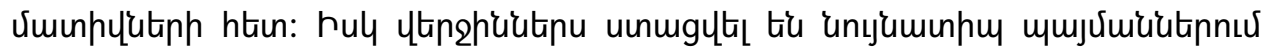

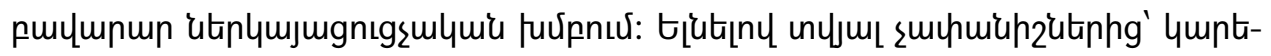

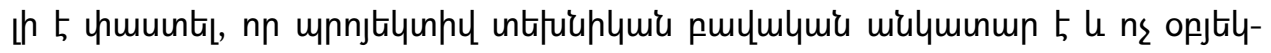
unhy [8, t, 67-79]:

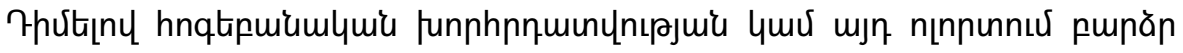

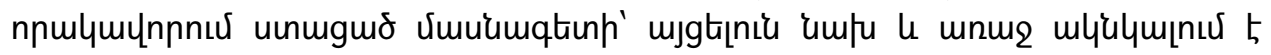

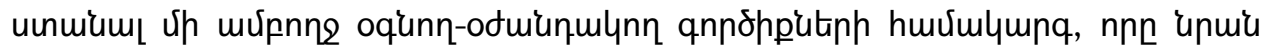

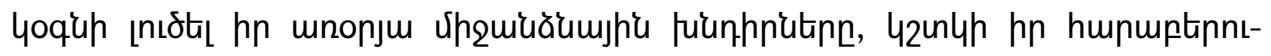

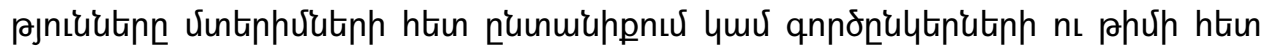

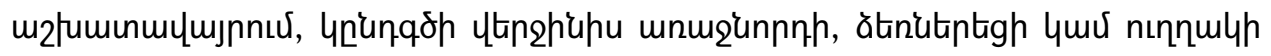

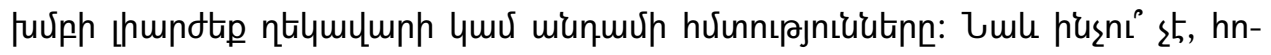

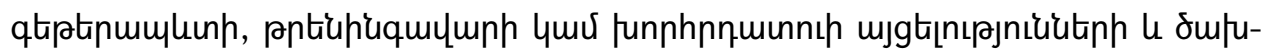

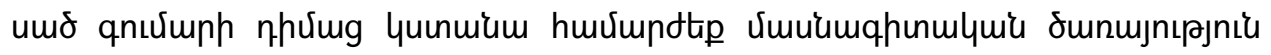

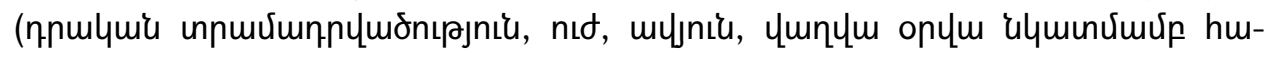

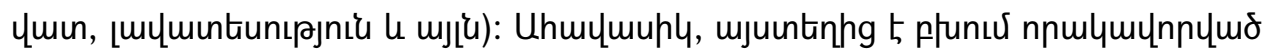

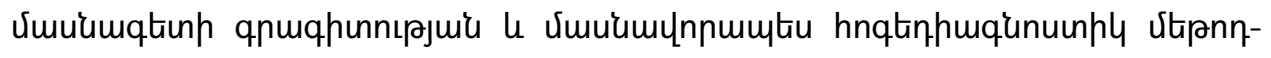

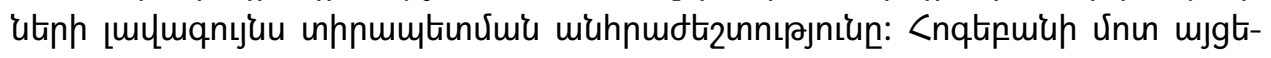

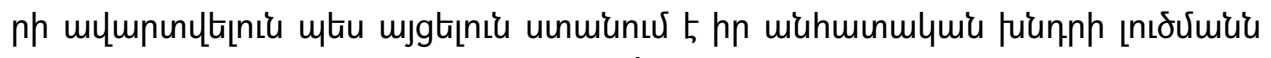

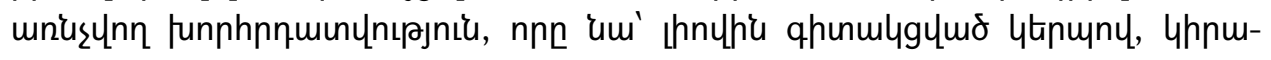

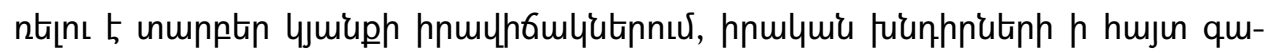

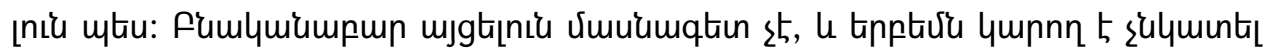

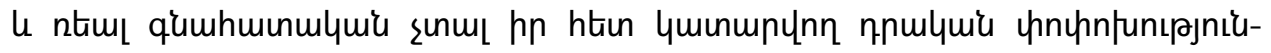

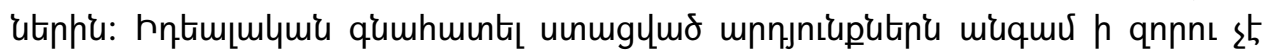

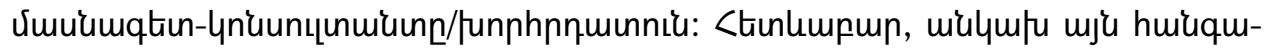

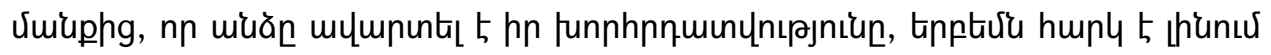

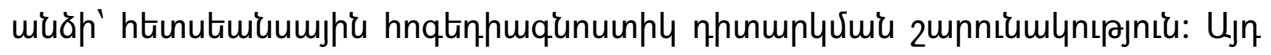

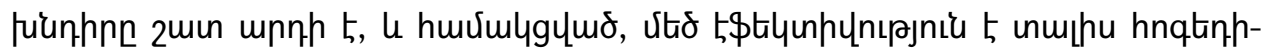

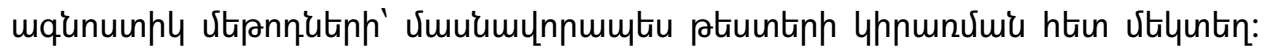

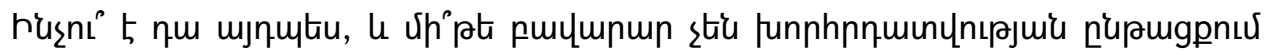

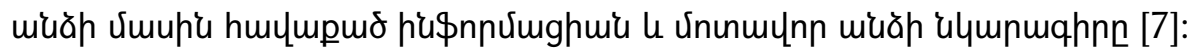

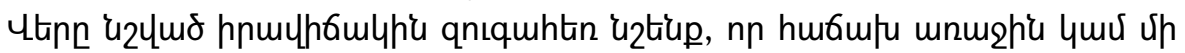

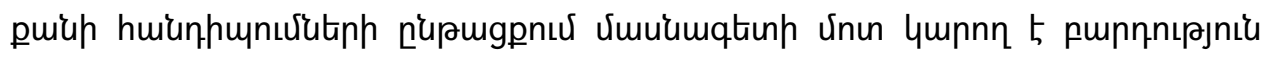

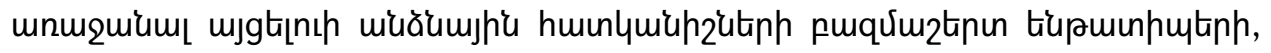

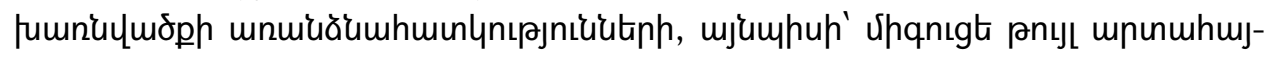

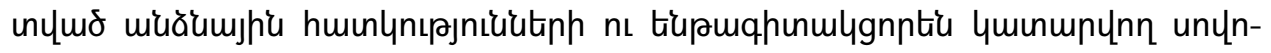

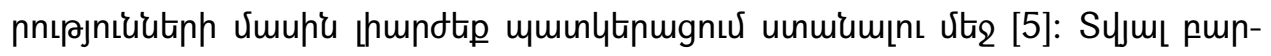

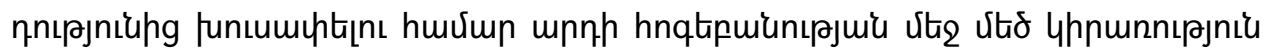

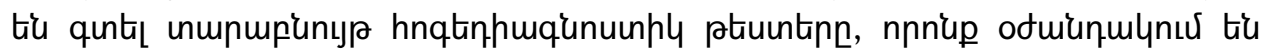




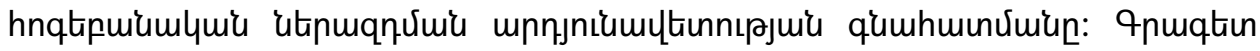

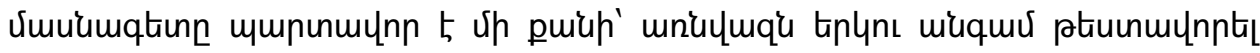

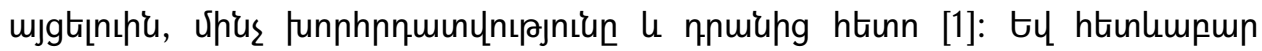

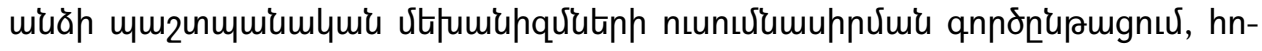

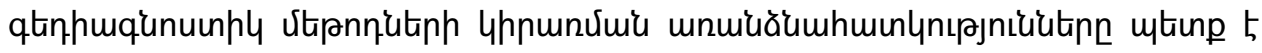

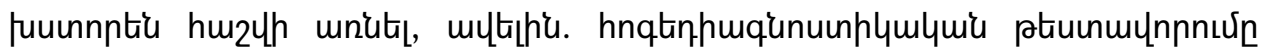

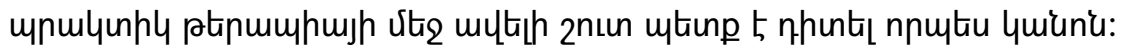

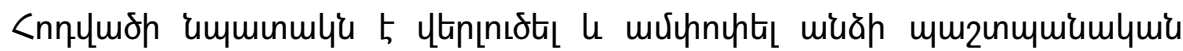

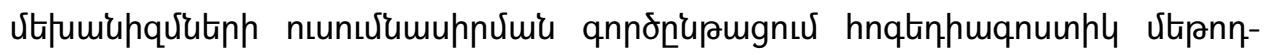

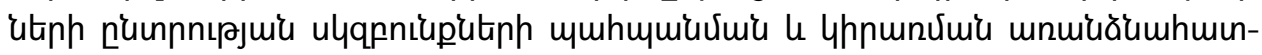

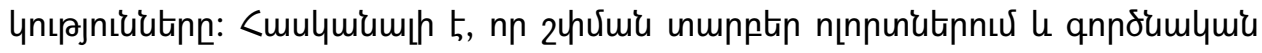

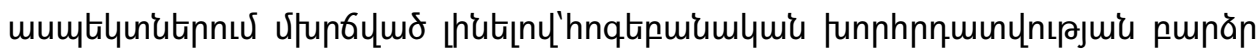

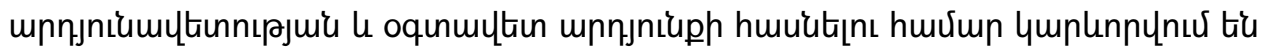

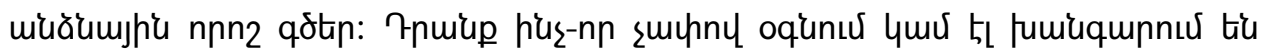

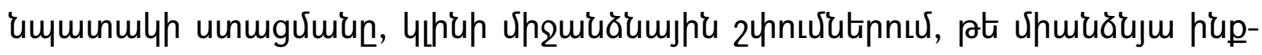

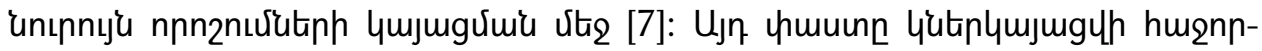

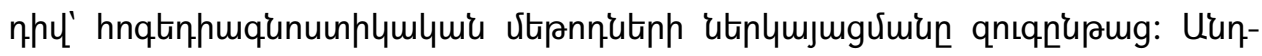

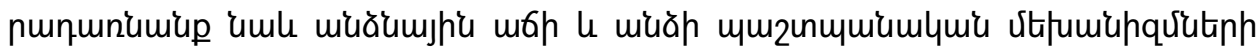

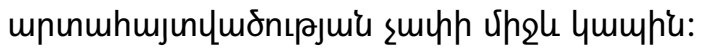

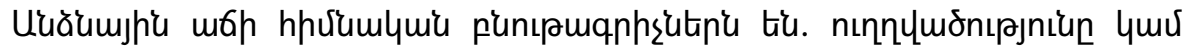

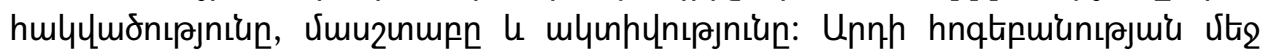

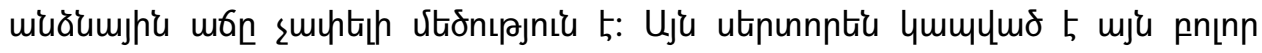

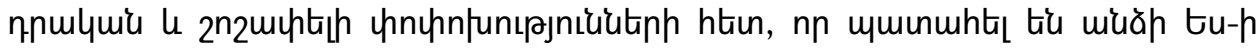

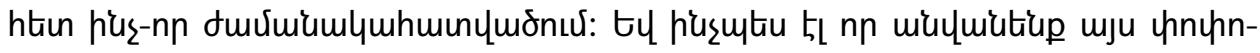

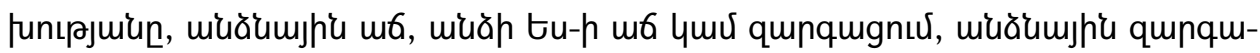

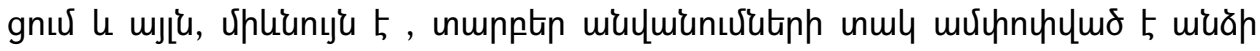

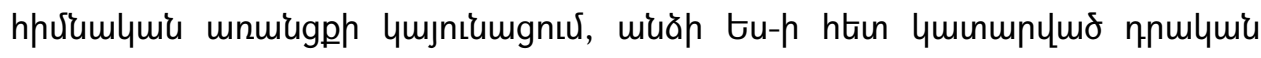

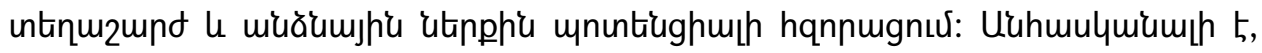

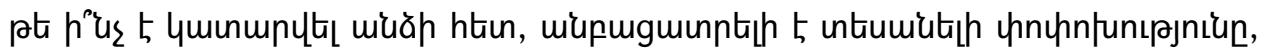

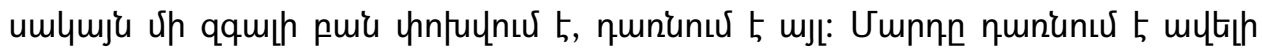

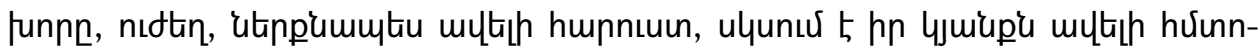

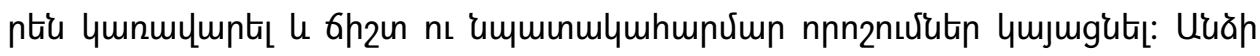

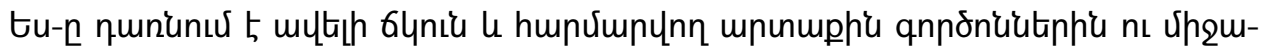
чujnhic [12]:

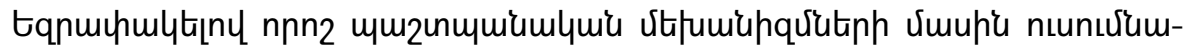

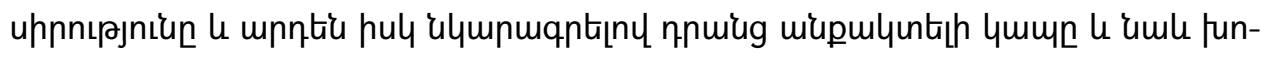

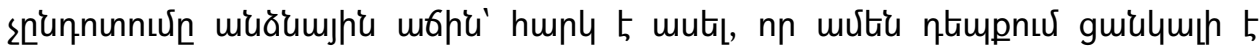

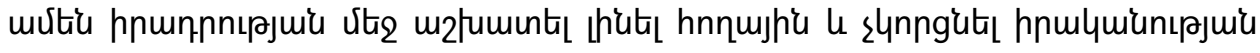

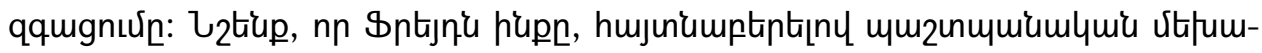

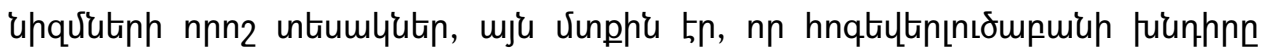




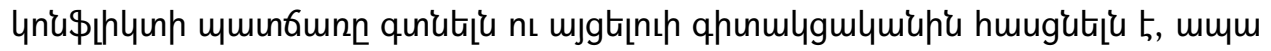

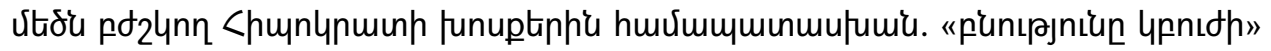

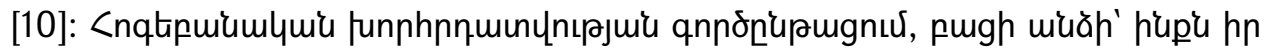

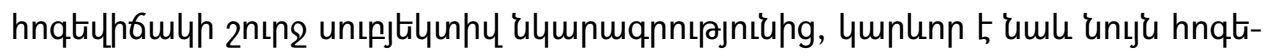

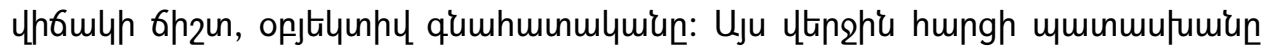

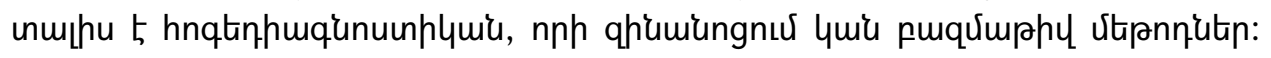

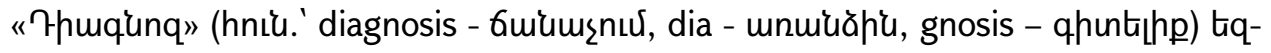

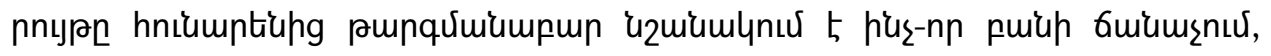

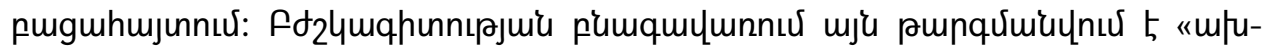

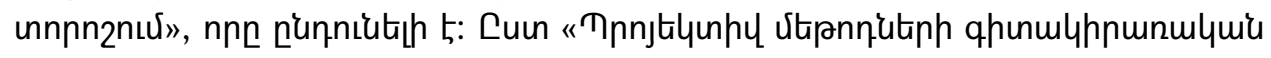

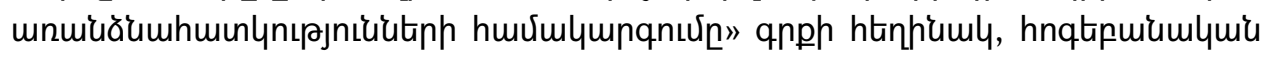

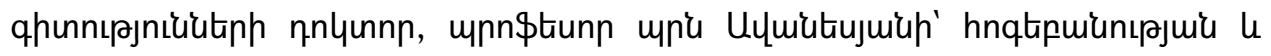

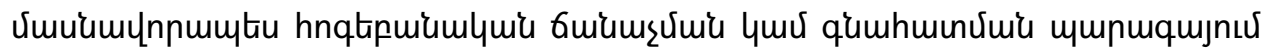

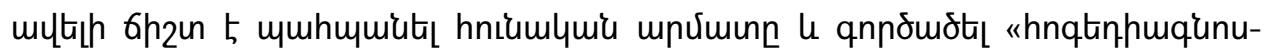

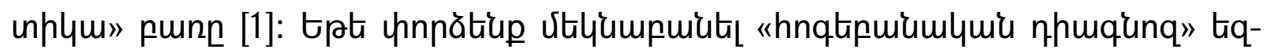

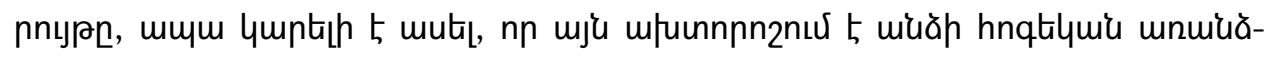

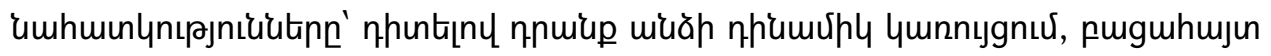

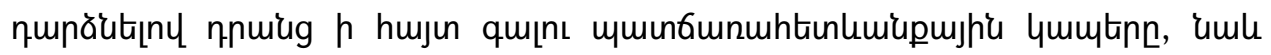

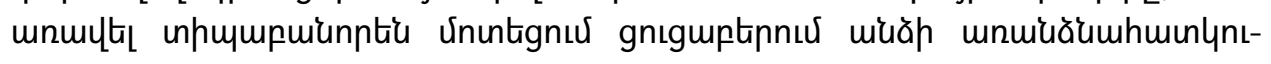

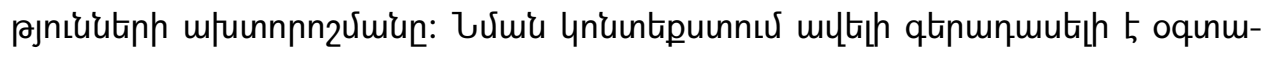

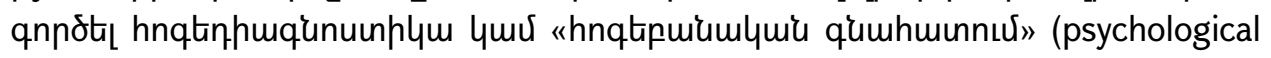

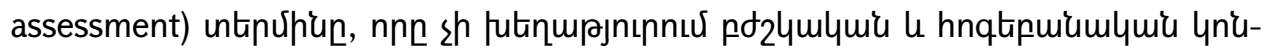

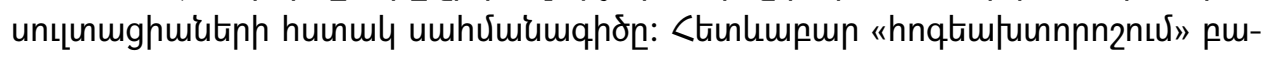

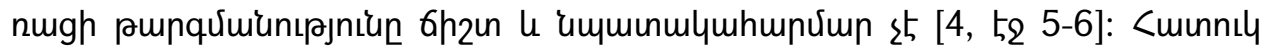

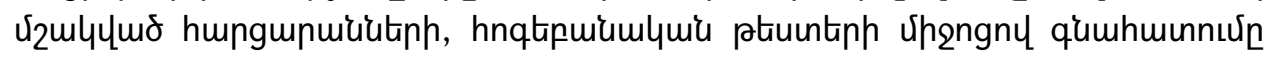

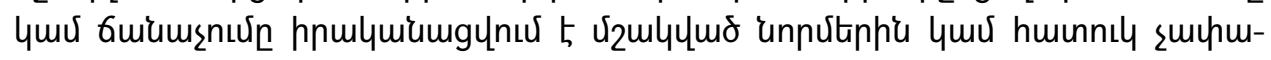

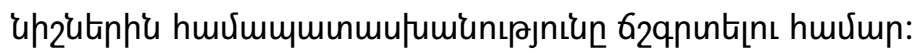

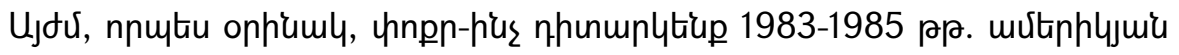

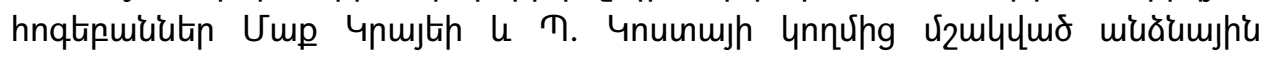

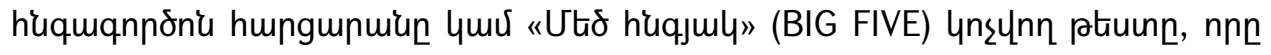

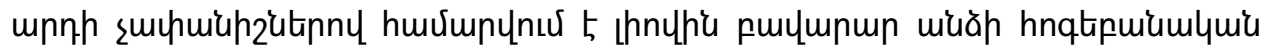

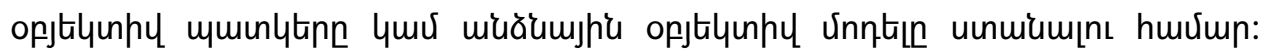

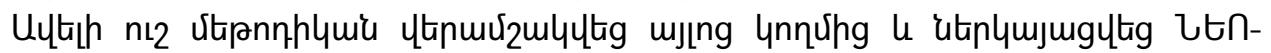

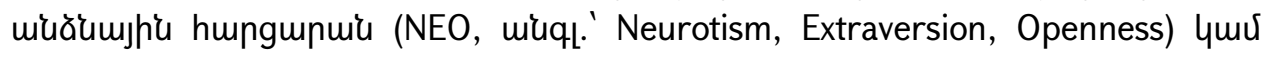

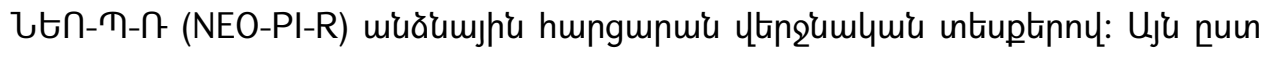

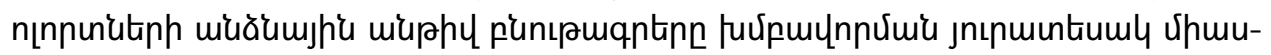

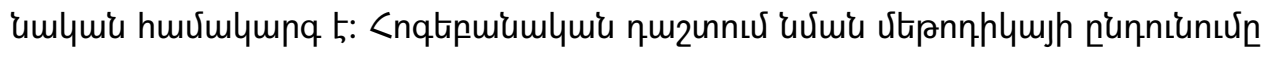

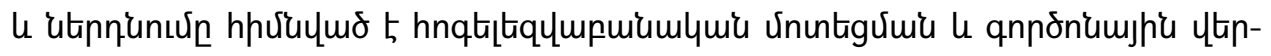

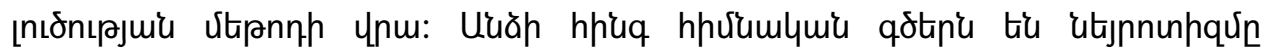

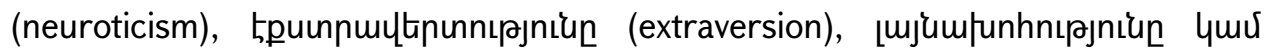




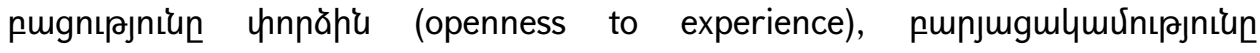

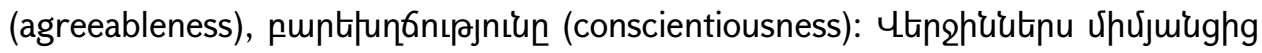

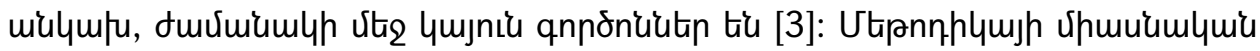

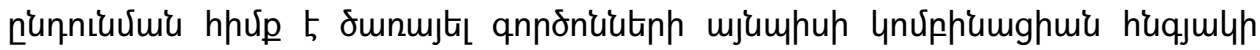

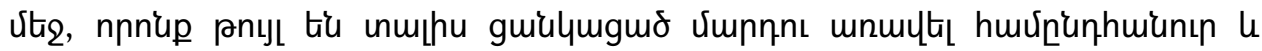

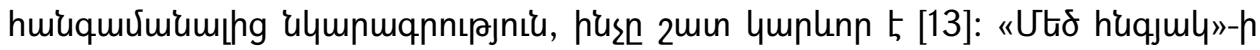

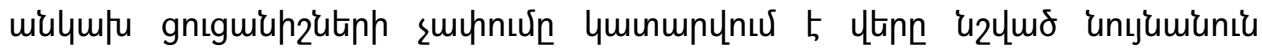

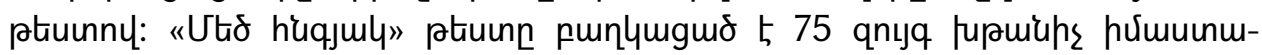

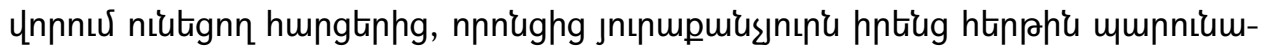

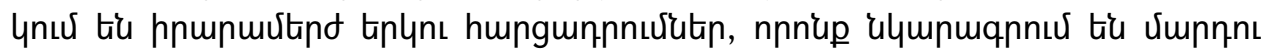

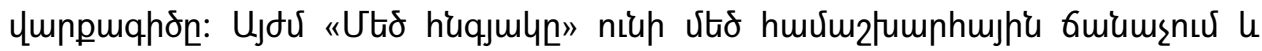

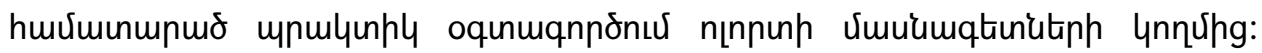

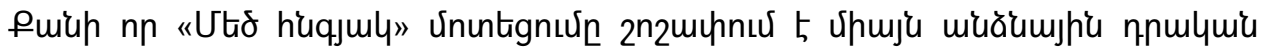

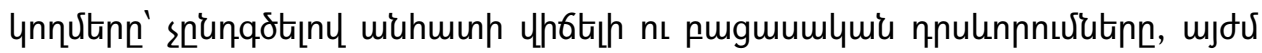

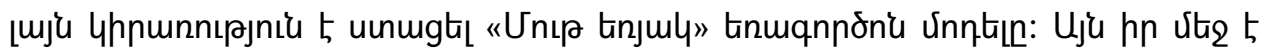

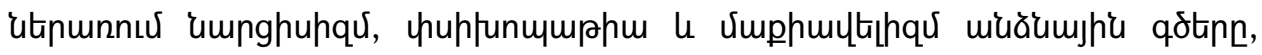

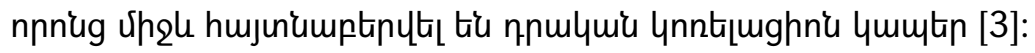

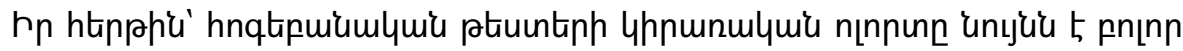

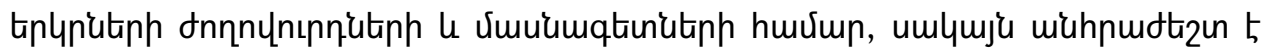

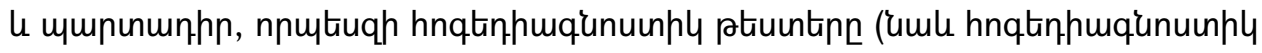

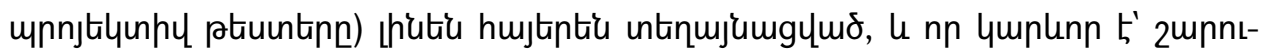

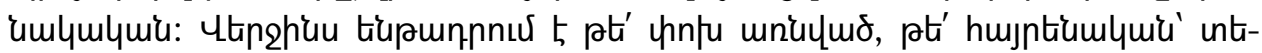

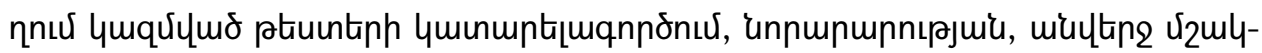

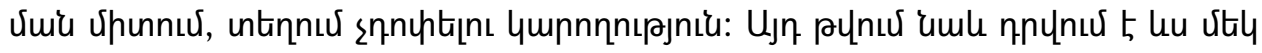

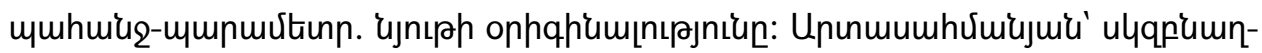

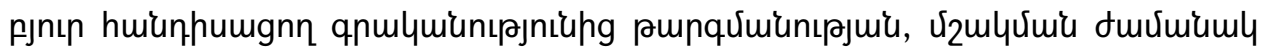

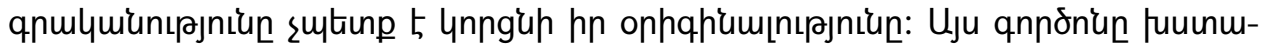

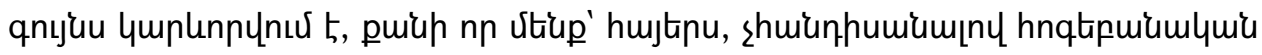

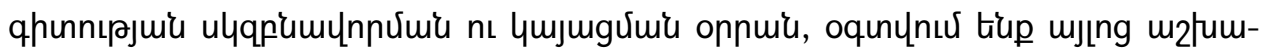

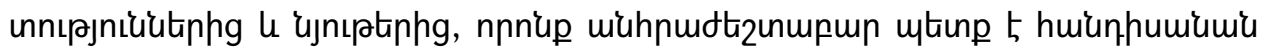

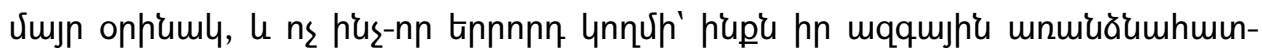

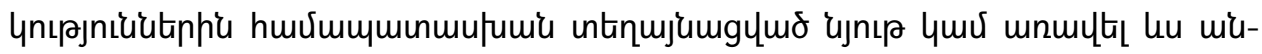

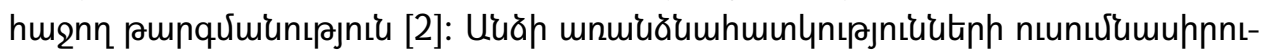

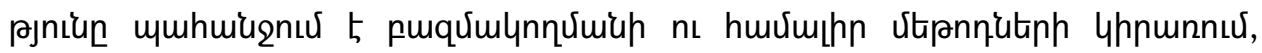

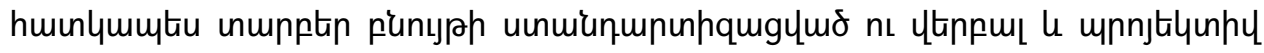

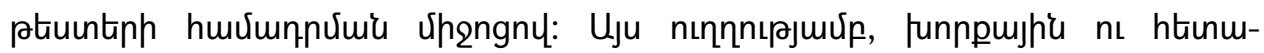

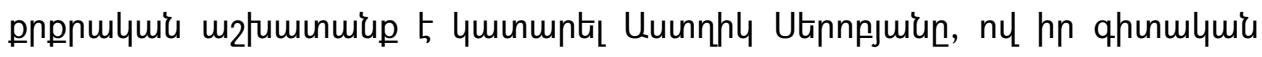

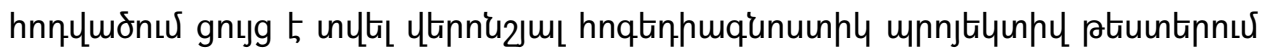

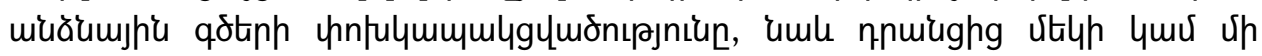

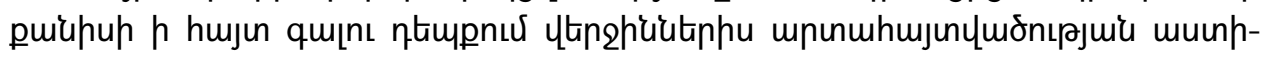




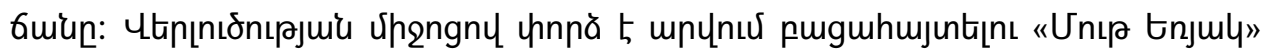

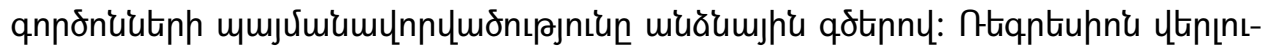

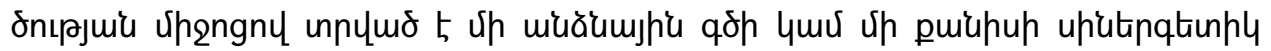

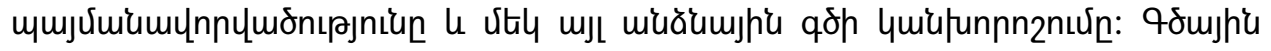

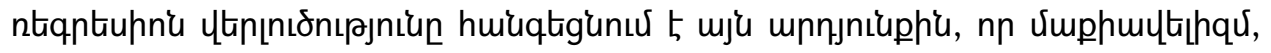

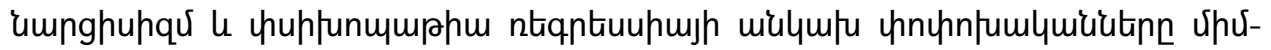

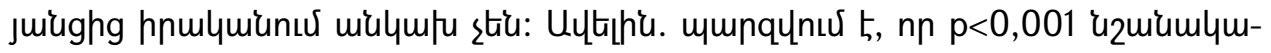

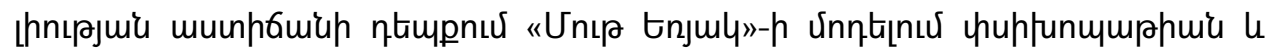

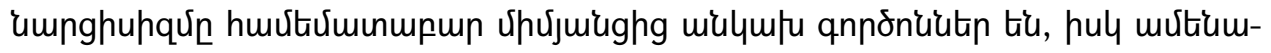

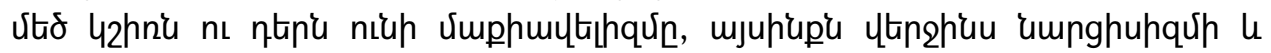

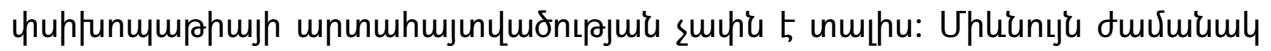

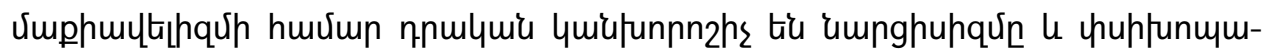

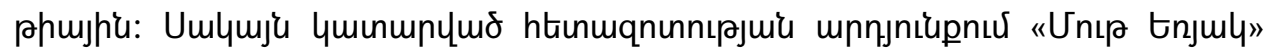

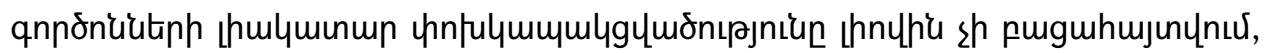

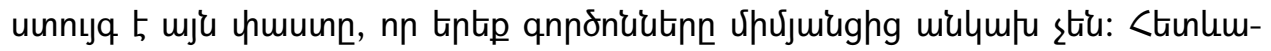

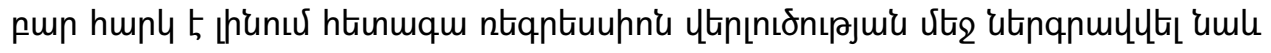

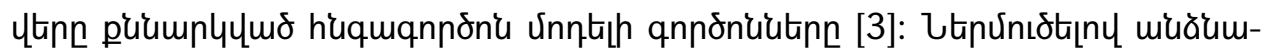

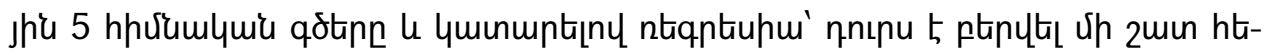

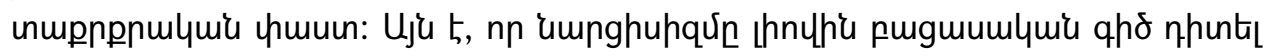

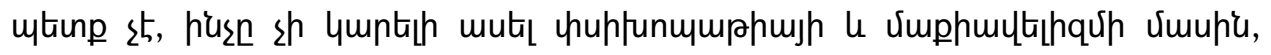

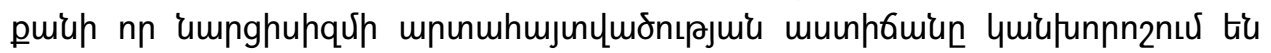

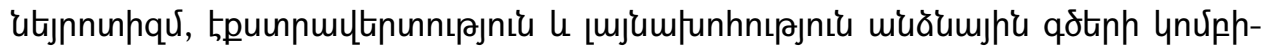

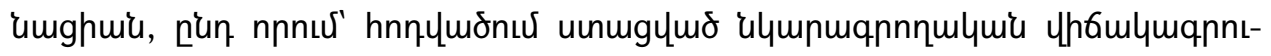

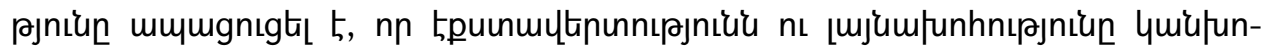

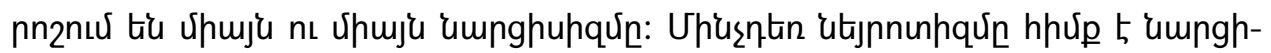

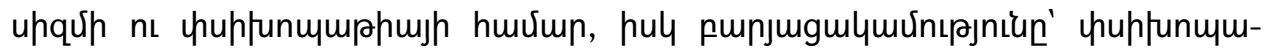

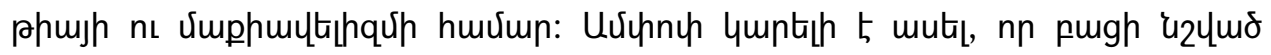

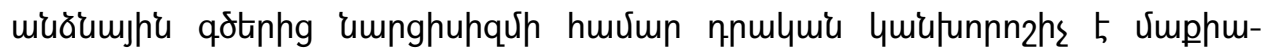

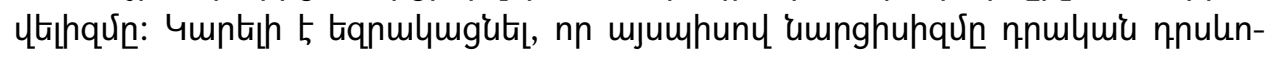

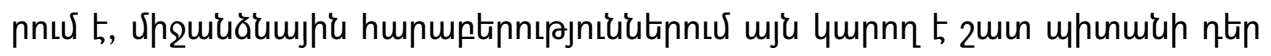

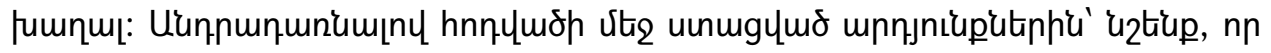

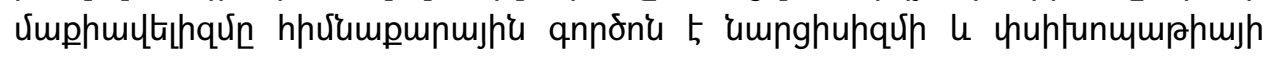

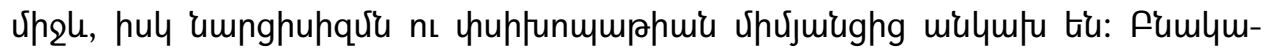

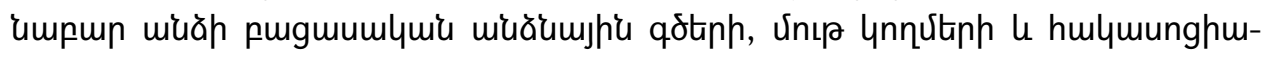

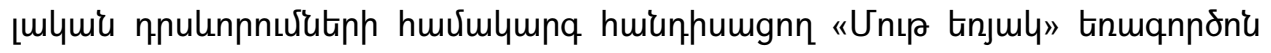

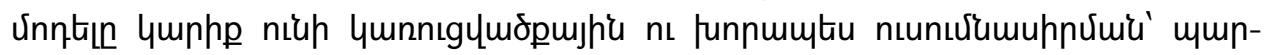

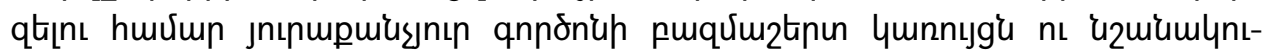

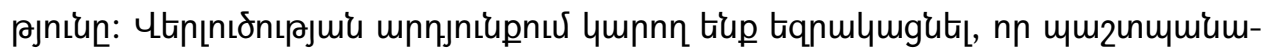

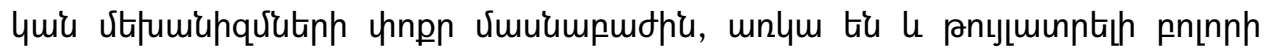

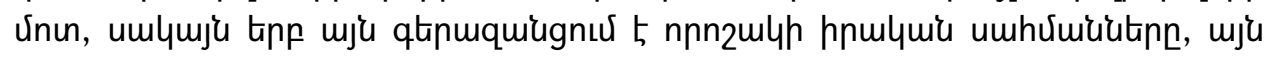




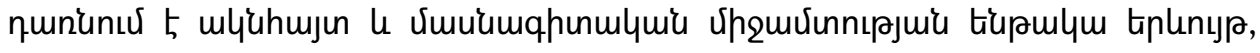

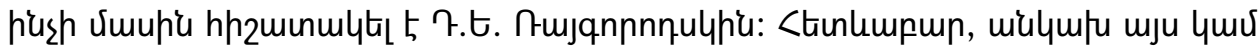

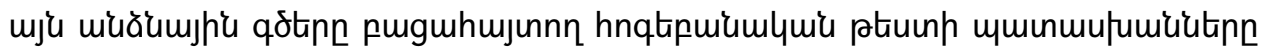

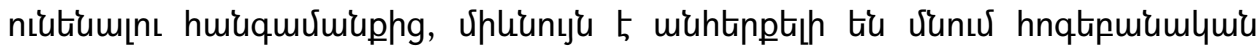

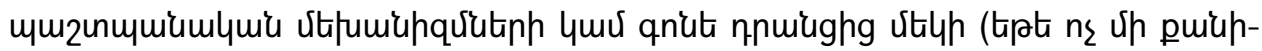

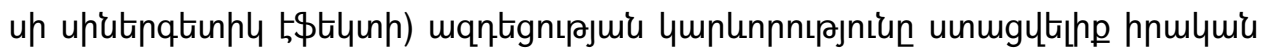

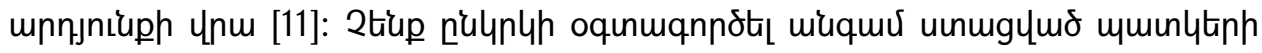

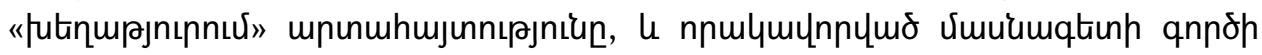

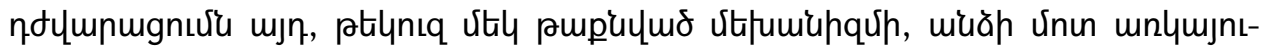

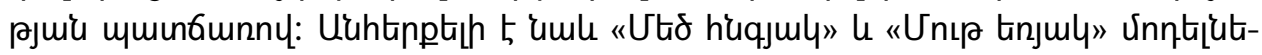

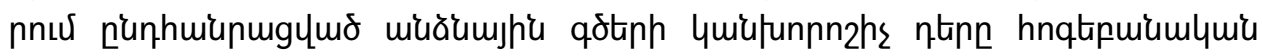

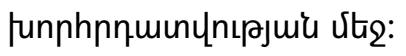

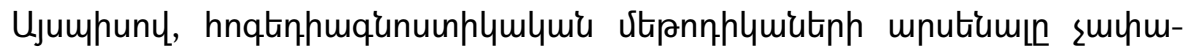

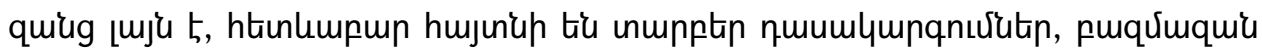

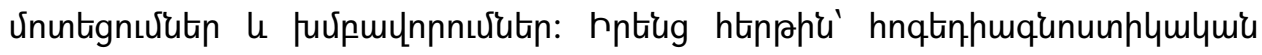

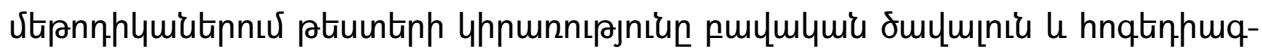

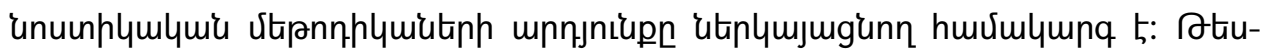

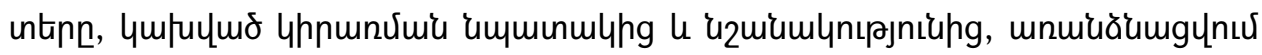

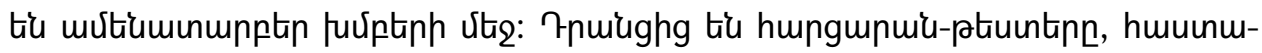

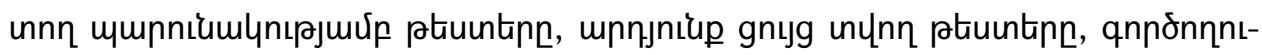

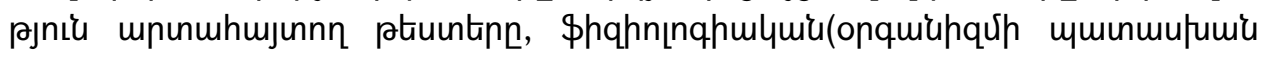

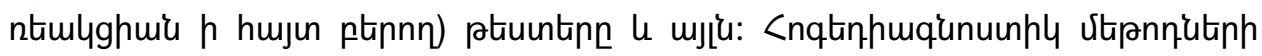

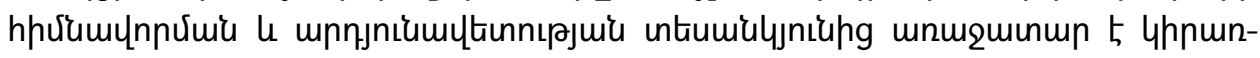

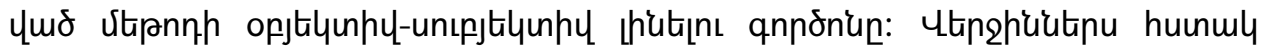

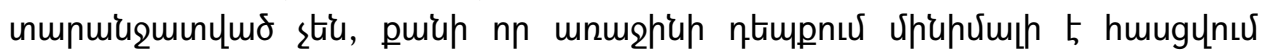

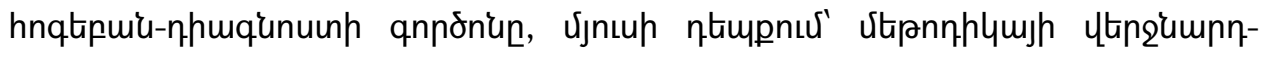

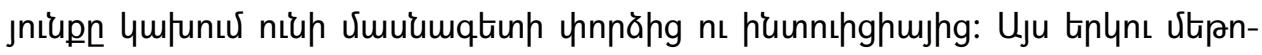

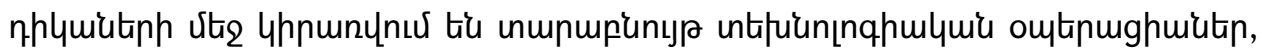

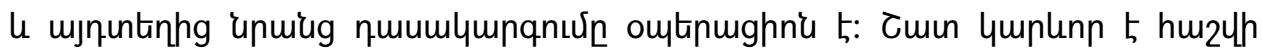

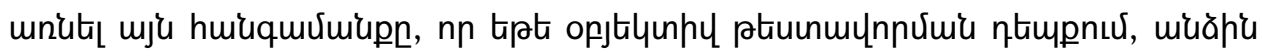

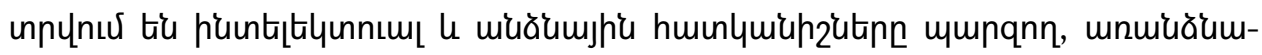

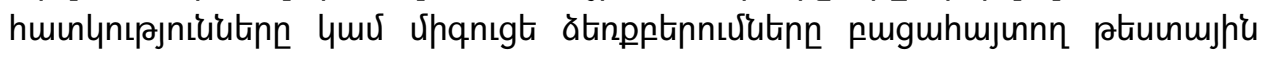

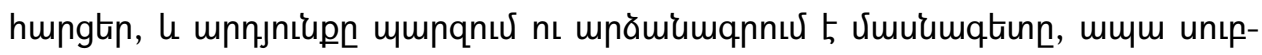

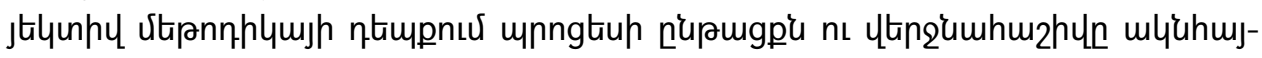

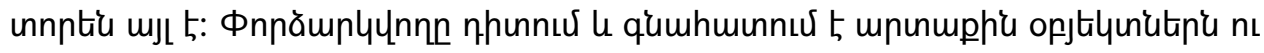

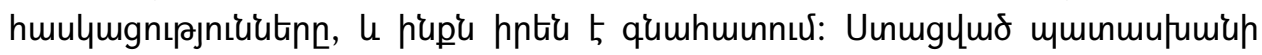

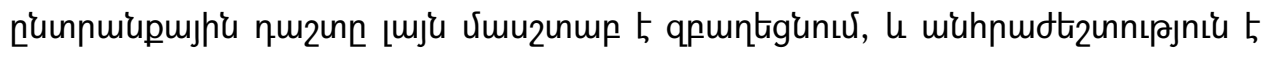

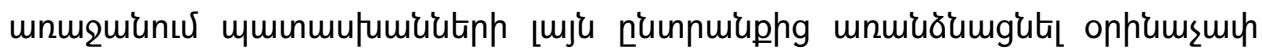

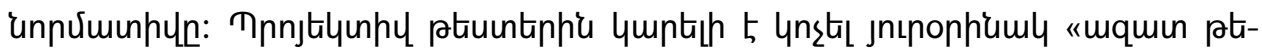

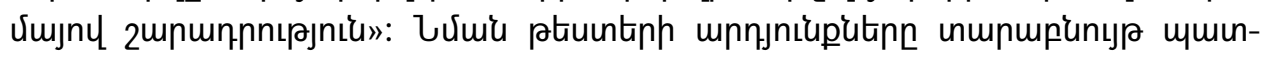




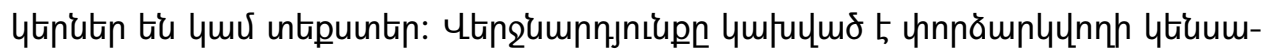

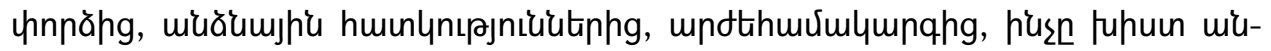

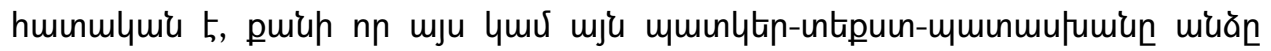

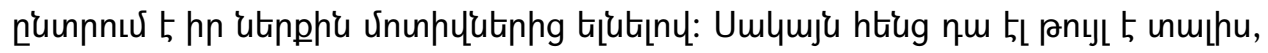

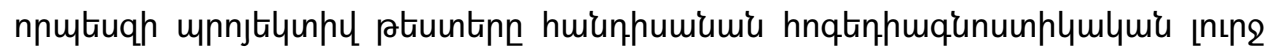

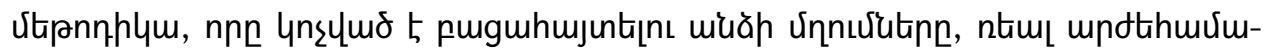

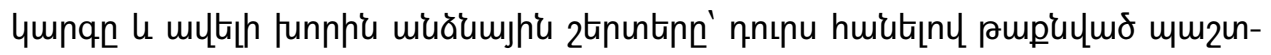

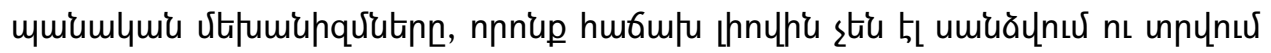

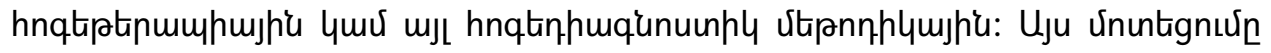

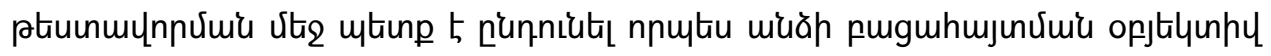

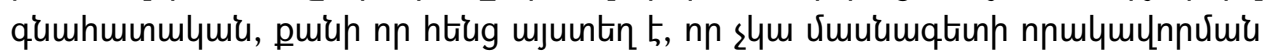

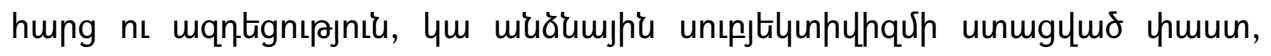

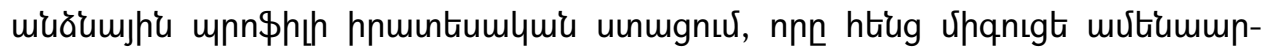

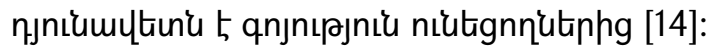

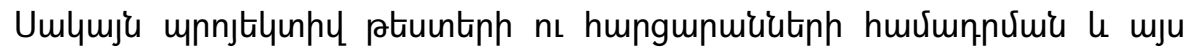

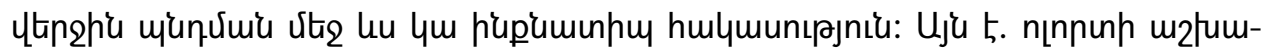

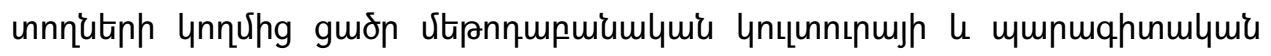

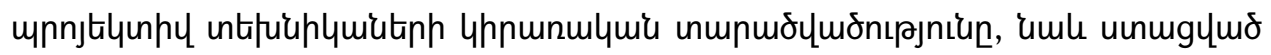

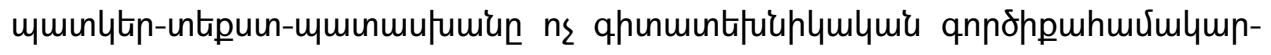

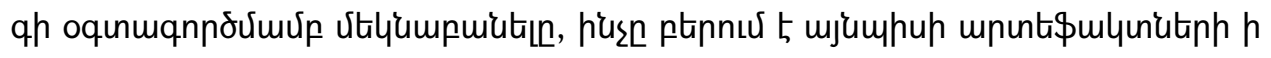

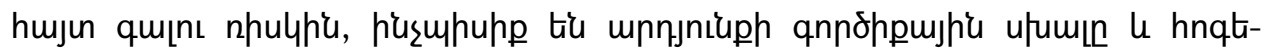

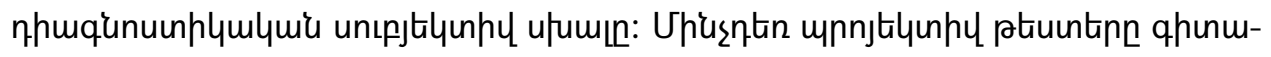

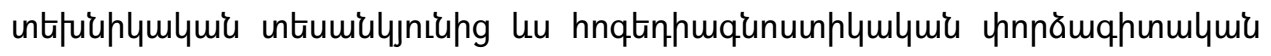

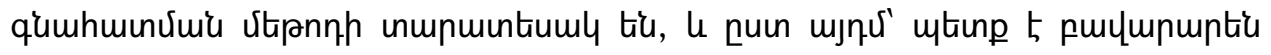

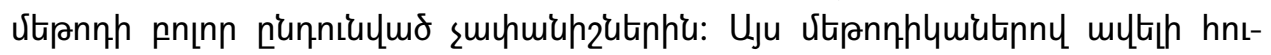

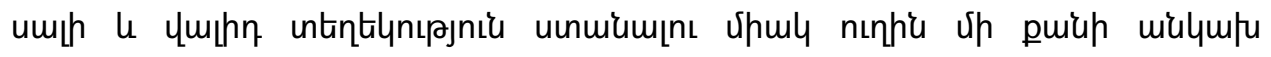

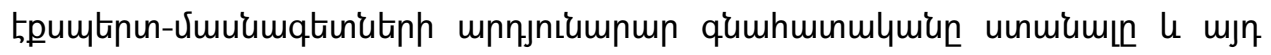

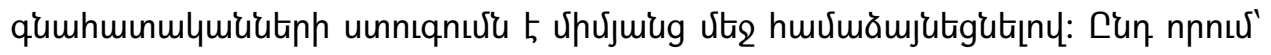

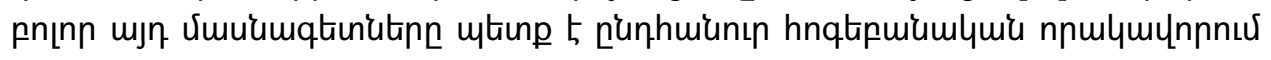

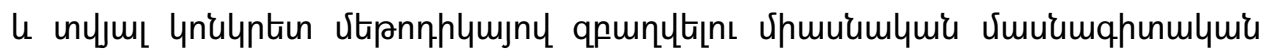

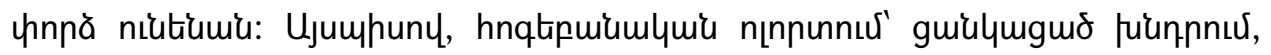

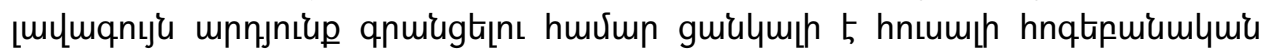

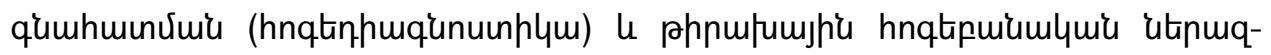

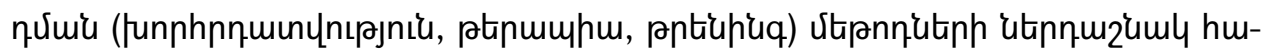

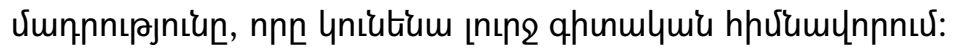




\section{9pulquiunıpjnıน}

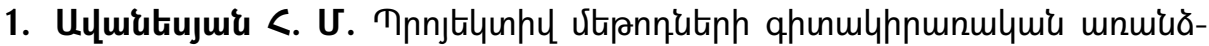

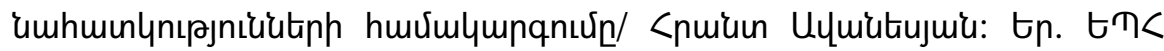
hnuin., 2017, 256 5:

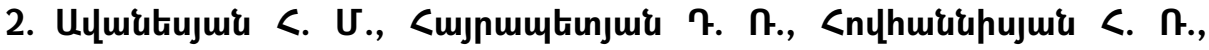

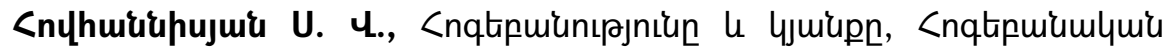

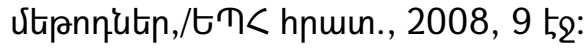

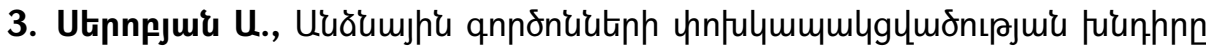

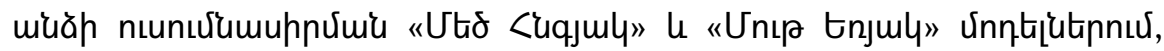

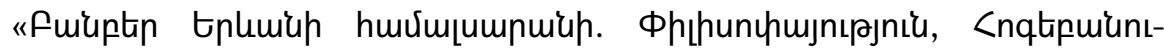
PJniu»/ ঢT< hpuin., 2019, 62-73 52 :

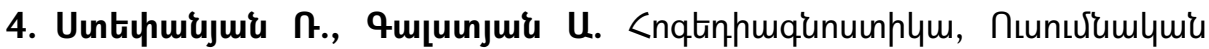

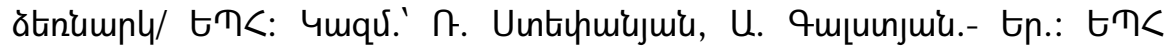
hpuin., 2012, 210 t2:

5. Кочюнас Р. Основы психологического консультирования, М.: "Академический проект" 1999, 240 с.

6. Негрий В. А. Психодиагностика и коррекция механизмов психологической защиты как фрактора сопротивления обучению//Журнал: Научное мнение, № 3, 2013, с. 175-180.

7. Немов Р. С. Н 50 Основы психологического консультирования: Учеб. для студ.Педвузов. М.:Гуманит. изд. центр ВЛАДОС, 1999.-394 c.//https://www.klex.ru/3a0, ujg' 06.12.2020.

8. Пантилеев С. Р. Жилина Е. Ю. Методика диагностики защитных механизмов личности//Вестник Московского университета. Серия 14. Психология, 2009, с. 67-79.

9. Райгородский Д. Я. Психология личности . Т.1. Хрестоматия. Издание третье, дополненное.- Самара: Издательский Дом БАХРАМ-М . 2002 $512 c$.

10.Романин А. Н. Основы психотерапии : учебник / А.Н. Поманин - М. : КНОРУС, 2006. - 528 c.

11. Райгорогский Д. Я. Практическая психодиагностика. Методики и тесты. Учебное пособие.- Самара: Издательский Дом «БАХРАМ-М», 2001. - 672c. https://brainmod.ru/tests/manual/psychological-defense/, mjg' 29.11.2020.

12. Козлов Н.И. Психоголос, Энциклопедия практической психологии, мужской и женский взгляд на личность, личностный рост и развитие, https://www.psychologos.ru/articles/view/muzhskoy-i-zhenskiy-vzglyad-nalichnostzpt-lichnostnyy-rost-i-razvitie, ujg' 07.12.2020. 
13.Хромов А.Б. Пятифакторный опросник личности: Учебно-методическое пособие. - Курган: Изд-во Курганского гос. университета, 2000. - 23 с., http://osp.kgsu.ru/hromov/5faktor.pdf, m.g' 30.11.2020.

14.Журавлев Д.В. Психодиагностика: классификация видов и типов, БимБад, (2009) http://www.bim-bad.ru/biblioteka/article_full.php?aid=132\& binn_rubrik_pl_articles=112 m.g' 04.12.2020.

15.Колеконова О.Е.,Павлов А.Н., КГБОУ "Красноярская Мариинская женская гимназия-интернат' '2010-2020 https://kmariinka.ru/index.php. ujg' 22.11.2010.

16.Болучевская В.В., Волчанский М.Е., Научно-исследовательская квалификационная (преддипломная) практика: методические указания для студентов по специальности «Клиническая психология», Волгоград: Издво Волг ГМУ, 2016. https://www.volgmed.ru/uploads/files/2018-11/96875metodicheskie_ukazaniya_po_nauchno-issledovatelskoj_praktike_ specialnosti_klinicheskaya_psihologiya_specialitet.pdf, (mjg' 15.11.2020)

\section{ОСОБЕННОСТИ ПРИМЕНЕНИЯ ПСИХОДИАГОСТИЧЕСКИХ МЕТОДОВ ПРИ ИЗУЧЕНИИ ЗАЩИТНЫХ МЕХАНИЗМОВ ЛИЧНОСТИ}

Карапетян М. А. (ЕГУ, Ереван, Армения)

В статье описаны защитные механизмы личности. Рассматривается обратная связь между личностным ростом и защитными механизмами. Актуальность статьи тесно связана с ее сутью и целью, а именно: В психологическом консультировании, особенно в процессе изучения защитных механизмов человека, следует строго учитывать особенности использования психодиагностических методов, стремясь к тому, чтобы точные методы психологической оценки в практической терапии рассматривались как правило, а не исключение из правил. Отмечается, что исходную и точную информацию о личных качествах и характеристиках посетителя можно получить с помощью психодиагностического тестирования. Представлена модель «Большой Пятерки», разработанная П. Костой и Р. МакКрэйем, которая сейчас наиболее объективно описывает черты личности человека. Он сочетается с трехфакторной моделью «Темной Триады», раскрывающей темные стороны человека. Отмечается также о необходимости оригинальности и постоянного улучшения исходного материала. Уделено внимание на ключевые характеристики психолога или высококвалифицированного человека, на основании котороых специалист может собрать мозаику ментального мира другого человека и дать положительный результат. 
Ключевые слова. личность, защитный механизм, психодиагностика, тесты, анкета, проекция.

\title{
CHARACTERISTIC FEATURES OF APPLICATION OF PSYCHODIAGNOSTIC METHODS IN THE STUDY OF PERSONAL PROTECTIVE MECHANISMS
}

\author{
Karapetyan M. A. (YSU, Yerevan, Armenia)
}

The article describes the protective mechanisms of the person. A reference is made to the inverse relationship between personal growth and defense mechanisms. The topicality of the article is closely connected with its essence and aim, e.i. in psychological consultation, especially in the process of studying the protective mechanisms of the person, the characteristic features of psychodiagnostic methods should be strictly taken into consideration, aspiring to the accurate methods of psychological estimation in practical therapy to be considered as a rule, rather than an exception to the rules. It is important to receive initial or accurate information about the visitor's personal traits and characteristics by means of psychodiagnostic testing. The model "Big Five", developed by P. Costa and R. McCray, is presented, which nowadays describes personality traits of people most objectively. It is combined with three-factor model "Dark Triad' that exposes the dark sides of the person. The need for originality and constant improvement of the source material is also noted. A reference is made to the main characteristics of the psychologist or of the highly skilled person, on the basis of which the specialist is authorized to assemble the mosaic of the mental world of the person in front of him and give a positive result.

Keywords: person, defense mechanism, psychodiagnostics, tests, questionnaire, projection. 